\title{
A COMPARISON OF UPPER LIMB AMPUTEES AND PATIENTS WITH UPPER LIMB INJURIES USING THE DISABILITY OF THE ARM, SHOULDER AND HAND (DASH).
}

\author{
Judith Davidson \\ Occupational Therapist \& Hand Therapist \\ Prince of Wales Hospital \\ Barker Street \\ RANDWICK. 2031
}

Phone 61293825930

Fax 61293890632

Email: judydav@bigpond.net.au

\section{Introduction}

Amputation of a limb represents a catastrophe for the adult amputee and their family. However data regarding the prosthetic, functional and psychological outcomes achieved by these patients is limited.

There is no well recognised outcome measure used throughout Australia, UK or America especially for aquired adult amputations of the upper limb. Most scales currently in use fail to identify the psychological adjustment problems which many of these amputees demonstrate. Many adult amputees continue to report significant behavioural limitations and discomfort, associated with low self-esteem, anxiety and depression when compared with an able-bodied control sample (1) $^{(1)}$

Phantom limb phenomena is also a well recognised problem for many upper limb amputees . Scales used to measure prosthetic use rarely investigate the impact pain has on the amputee and his or her well being.

The Disability of the Arm Shoulder and Hand Scale (DASH) is an evaluative outcome measure for patients with upper extremity musculoskeletal conditions designed in the mid 1990s by the American Academy of Orthopaedic Surgeons and Toronto Institute for Work and Health $(2,3,4)$ It is a region specific questionnaire as opposed to diagnosis specific questionnaire. It measures function \& symptoms of musculo-skeletal disorders in upper limb.

The DASH was able to demonstrate change in all situations in which change was presumed to have occurred. The DASH was found to have comparable responsiveness to the joint specific measures. It demonstrated suitable levels of sensitivity and specificity.

\section{Method:}

In 2004 I had a paper published by Disability and Rehabilitation reporting the outcomes of a cohort of 275 patients between 1998 and $2003^{.(5)}$

\section{Results:}

The diagnoses, number of respondents, average age and the compensability of the patients is recorded in Table 1 along with the average DASH score. 
Table 1: The total cohort of patients completing the DASH

\begin{tabular}{|c|c|c|c|c|c|c|}
\hline Diagnosis & $\begin{array}{l}\text { No. } \\
\text { patients }\end{array}$ & $\begin{array}{l}\text { Ave. } \\
\text { age }\end{array}$ & $\begin{array}{l}\text { Mean } \\
\text { Dash } \\
\text { Score }\end{array}$ & $\begin{array}{l}\text { Standard } \\
\text { Deviation }\end{array}$ & $\begin{array}{l}\text { No. } \\
\text { compensable }\end{array}$ & $\begin{array}{l}\text { No. non } \\
\text { compensable }\end{array}$ \\
\hline $\begin{array}{l}\text { Quadruple } \\
\text { amputations }\end{array}$ & 4 & 33 & 67 & 18 & 0 & 4 \\
\hline $\begin{array}{l}\text { Bilateral } \\
\text { upper limb } \\
\text { amputations }\end{array}$ & 2 & 42 & 68 & 5 & 2 & 0 \\
\hline $\begin{array}{l}\text { Major } \\
\text { unilateral } \\
\text { upper limb } \\
\text { amputation }\end{array}$ & 39 & 42 & 39 & 20 & 19 & 20 \\
\hline $\begin{array}{l}\text { Partial hand } \\
\text { amputation }\end{array}$ & 26 & 38 & 49 & 22 & 16 & 10 \\
\hline $\begin{array}{l}\text { Amputation } \\
\text { following } \\
\text { brachial } \\
\text { plexus } \\
\text { injury }\end{array}$ & 8 & 35 & 37 & 16 & 5 & 3 \\
\hline $\begin{array}{l}\text { Brachial } \\
\text { plexus }\end{array}$ & 10 & 33 & 65 & 15 & 8 & 2 \\
\hline CRPS & 42 & 38 & 68 & 19 & 40 & 2 \\
\hline Arm pain & 21 & 41 & 50 & 22 & 15 & 6 \\
\hline $\begin{array}{l}\text { Carpal } \\
\text { tunnel }\end{array}$ & 13 & 56 & 40 & 21 & 4 & 9 \\
\hline Fracture & 4 & 43 & 30 & 23 & 3 & 1 \\
\hline Arthritis & 10 & 47 & 37 & 14 & 5 & 5 \\
\hline Hand Injury & 6 & 44 & 53 & 19 & 5 & 1 \\
\hline $\begin{array}{l}\text { Radiating } \\
\text { from neck }\end{array}$ & 16 & 40 & 58 & 16 & 16 & 1 \\
\hline Shoulder & 37 & 46 & 51 & 17 & 33 & 4 \\
\hline Tendonitis & 25 & 42 & 51 & 22 & 18 & 7 \\
\hline Wrist & 14 & 40 & 49 & 17 & 10 & 4 \\
\hline Total & 274 & 41 & 51 & 21 & 195 & 79 \\
\hline
\end{tabular}

There are 75 upper limb amputees in the cohort and 26 of these have had partial hand or digit amputations. The remaining 200 patients have suffered a variety of diagnoses including Complex Regional Pain Syndrome, Shoulder Capsulitis, Carpal Tunnell Syndrome, and Brachial Plexus injuries.

The average DASH score for the whole cohort was 51/100. The highest average DASH scores were for bilateral amputations (68/100) and quadruple amputations (67/100) and patients with Complex Regional Pain Syndrome (68/100). The lowest average score was 30/100 for fractures. These diagnostic differences are significant $(f=4.809 p=.000)$.

There are major differences within the scores by both diagnosis and compensability. Of the total cohort, $75 \%$ of injuries were covered by workers compensation or motor vehicle accident insurance. Within the highest 50 
scores $96 \%$ (47) of patients were compensable. However in the lowest 50 scores $56 \%$ of injuries were compensable.

Even the diagnoses of the patients in cohort do not appear to be evenly distributed between the top and lower end of the scale. In the highest 50 scores there are 19 patients with complex regional pain syndrome but only 7 amputees (and 4 of these were partial hand amputees). Within the lowest 50 scores there are 22 unilateral major upper limb amputees and only 2 patients with complex regional pain syndrome.

The mean DASH score for different groups of patients by their compensability is listed in Table 2. When all the 274 patients are compared by whether or not the injury was compensable there are significant differences. The non compensable patients have an average DASH score 15 units lower $(f=29.15 p=.000)$. The difference between compensable and non compensable amputees is 12 units lower $(f=5.612 p=.02)$.

Table 2: Comparison of DASH Scores by compensability of the patients:

\begin{tabular}{|c|c|c|c|c|}
\hline Compensability & No & $\begin{array}{l}\text { Mean Dash } \\
\text { Score }\end{array}$ & SD & Anova \\
\hline $\begin{array}{l}\text { All Compensable } \\
\text { participants }\end{array}$ & 196 & 56 & 21 & \multirow[t]{2}{*}{$\begin{array}{l}F 29.15 \\
P=.000\end{array}$} \\
\hline $\begin{array}{l}\text { All non- } \\
\text { compensable } \\
\text { participants }\end{array}$ & 76 & 41 & 18 & \\
\hline $\begin{array}{l}\text { Compensable } \\
\text { amputees }\end{array}$ & 42 & 50 & 23 & \multirow[t]{2}{*}{$\begin{array}{l}F 5.612 \\
P=.02\end{array}$} \\
\hline $\begin{array}{l}\text { Non compensable } \\
\text { amputees }\end{array}$ & 33 & 38 & 19 & \\
\hline
\end{tabular}

Table 3: Comparison of DASH Scores and their standard deviation between amputees and non-amputees

\begin{tabular}{|l|l|l|l|l|}
\hline Category & No. & $\begin{array}{l}\text { Mean Dash } \\
\text { Score }\end{array}$ & SD & Anova \\
\hline Amputee & 75 & 45 & 22 & $\mathrm{~F}=10.18$ \\
$\mathrm{P}=.002$
\end{tabular}

Table 3 shows the mean DASH scores for amputees compared to nonamputees. There is a 9 unit difference which is significant $(f=10.18 p=.002)$ 
Table 4: Comparison of Dash Score and their standard deviation by level of amputation

\begin{tabular}{|c|c|c|c|c|}
\hline Amputation level & No. & $\begin{array}{l}\text { Mean Dash } \\
\text { Score }\end{array}$ & SD & Anova \\
\hline Bilateral and quadruple & 6 & 67 & 14 & \multirow{4}{*}{$\begin{array}{l}F=3.95 \\
P=.012\end{array}$} \\
\hline $\begin{array}{l}\text { Brachial plexus } \\
\text { proceeding to amputation }\end{array}$ & 8 & 37 & 16 & \\
\hline $\begin{array}{l}\text { Major upper limb } \\
\text { amputation }\end{array}$ & 35 & 39 & 21 & \\
\hline Partial hand & 26 & 49 & 22 & \\
\hline
\end{tabular}

Table 4 shows the mean DASH scores for amputees by level of amputation. The mean score for brachial plexus injuries not proceeding to amputation was 65 compared to 37 for those brachial plexus injuries who have proceeded to amputation. The mean score for major unilateral upper limb amputation was 39/100 compared to partial hand amputation which was 49/100. This difference was significant . ( $F=3.95$. and $p=.012)$

The DASH score includes components for symptomatology (pain) and psychosocial status (esteem). Table 5 shows the mean esteem and pain scores for amputees compared to non-amputees and there is no significant difference.

Table 5: Comparison of Pain and Self-esteem Scores and their standard deviation between amputees and non-amputees

\begin{tabular}{|l|l|l|l|l|l|}
\hline Category & No. & $\begin{array}{l}\text { Mean } \\
\text { Pain } \\
\text { Score }\end{array}$ & $\begin{array}{l}\text { Pain } \\
\text { SD }\end{array}$ & $\begin{array}{l}\text { Mean Esteem } \\
\text { Score }\end{array}$ & $\begin{array}{l}\text { Esteem } \\
\text { SD }\end{array}$ \\
\hline Amputee & 75 & 19 & 16 & 10 & 3 \\
\hline Non amputee & 199 & 20 & 5 & 12 & 6 \\
\hline Anova & & $\begin{array}{l}\mathrm{P}=.515 \\
\mathrm{~F}=.425\end{array}$ & & $\begin{array}{l}\mathrm{P}=.017 \\
\mathrm{~F}=5.73\end{array}$ & \\
\hline
\end{tabular}

The symptomatology and psycho-social scores for different levels of amputation are listed in Table 6. The psycho-social status between the groups of amputees was significant ( $f=4.46$ with $p$.002) . There was no significant difference in the pain scores. 
Table 6 : Mean Pain and Self Esteem Scores and their standard deviations by level of amputation

\begin{tabular}{|l|l|l|l|l|l|}
\hline Amputation & No. & $\begin{array}{l}\text { Mean Pain } \\
\text { Score }\end{array}$ & $\begin{array}{l}\text { Pain } \\
\text { SD }\end{array}$ & $\begin{array}{l}\text { Mean } \\
\text { Esteem } \\
\text { Score }\end{array}$ & $\begin{array}{l}\text { Esteem } \\
\text { SD }\end{array}$ \\
\hline $\begin{array}{l}\text { Bilateral and } \\
\text { quadruple }\end{array}$ & 6 & 16 & 6 & 13 & 1 \\
\hline $\begin{array}{l}\text { Brachial plexus } \\
\text { proceeding to } \\
\text { amputation }\end{array}$ & 8 & 20 & 8 & 9 & 3 \\
\hline $\begin{array}{l}\text { Major upper limb } \\
\text { amputation }\end{array}$ & 35 & 19 & 23 & 9 & 3 \\
\hline Partial hand & 26 & 19 & 16 & 11 & 2 \\
\hline $\begin{array}{l}\text { Anova - significance } \\
\text { between levels }\end{array}$ & & $\begin{array}{l}\mathrm{F}=.069 \\
\mathrm{P}=.96\end{array}$ & & $\begin{array}{l}\mathrm{F}=4.465 \\
\mathrm{P}=.002\end{array}$ & \\
\hline
\end{tabular}

Table 7 indicates the mean DASH scores for the 48 patients recorded on assessment and after treatment. The numbers are small in each of the categories.

Table 7: Comparison of Assessment and post Treatment Scores using the DASH.

\begin{tabular}{|l|l|l|l|l|}
\hline Diagnosis & $\begin{array}{l}\text { No. } \\
\text { patients }\end{array}$ & $\begin{array}{l}\text { Mean } \\
\text { total } \\
\text { Dash } \\
\text { score }\end{array}$ & $\begin{array}{l}\text { Mean total } \\
\text { Dash score } \\
\text { post } \\
\text { treatment }\end{array}$ & $\begin{array}{l}\text { Change in } \\
\text { scores }\end{array}$ \\
\hline Quadruple amputations & 1 & 82 & 47 & Down 35 \\
\hline $\begin{array}{l}\text { Major upper limb } \\
\text { amputation }\end{array}$ & 9 & 60 & 45 & Down 15 \\
\hline Partial hand amputation & 3 & 60 & 47 & Down 13 \\
\hline $\begin{array}{l}\text { Brachial plexus } \\
\text { proceeding to } \\
\text { amputation }\end{array}$ & 1 & 37 & 20 & Down 17 \\
\hline Brachial Plexus & 3 & 72 & 47 & Down 25 \\
\hline CRPS & 10 & 72 & 52 & Down 20 \\
\hline Arm pain & 2 & 69 & 51 & Down 18 \\
\hline Arthritis & 2 & 51 & 46 & Down 5 \\
\hline Hand injury & 2 & 65 & 63 & Down 2 \\
\hline Radiating from neck & 1 & 61 & 68 & Up 7 \\
\hline Shoulder & 8 & 61 & 36 & Down 25 \\
\hline Tendonitis & 3 & 63 & 43 & Down 20 \\
\hline Wrist & 3 & 55 & 19 & Down 26 \\
\hline Total & 48 & 64 & 44 & Down 20 \\
\hline
\end{tabular}


However, all of the categories of patients except those with pain radiating from the neck showed an improved health status in their DASH scores. Using the paired samples $T$ test the result is significant $(t=4.24 p=$ $.000)$. Of the 14 amputees who were reassessed, $7(50 \%)$ showed improved health status, 3 (21\%) were unchanged and $4(29 \%)$ had a diminished health status. Of the remaining 34 patients $26(78 \%)$ showed improved health status, 4 (11\%) were unchanged and $4(11 \%)$ showed a diminished health status.

Table 8 lists the mean DASH scores by diagnosis of the patients who completed the Work and/or Leisure module. Patients with Complex

Regional Pain Syndrome and Brachial Plexus injuries saw themselves as just as disabled with work and leisure tasks as they did with their normal tasks. However, unilateral major upper limb amputees, amputees from brachial plexus injuries and partial hand amputees saw themselves as having a greater disability affecting work tasks. Interestingly multiple limb amputees and patients with shoulder injuries and fractures saw themselves as being more affected in leisure tasks than work tasks.

Table 8: Mean scores for the Work and Leisure module by diagnosis.

\begin{tabular}{|l|l|l|l|l|l|}
\hline Diagnosis & $\begin{array}{l}\text { Mean } \\
\text { Dash } \\
\text { Score }\end{array}$ & $\begin{array}{l}\text { No. } \\
\text { Leisure } \\
\text { module } \\
\text { patients }\end{array}$ & $\begin{array}{l}\text { Mean } \\
\text { Leisure } \\
\text { score }\end{array}$ & $\begin{array}{l}\text { No. } \\
\text { Work } \\
\text { module } \\
\text { patients }\end{array}$ & $\begin{array}{l}\text { Mean } \\
\text { Work } \\
\text { score }\end{array}$ \\
\hline Multiple upper limb amputations & 67 & 4 & 83 & 3 & 77 \\
\hline Major upper limb amputation & 39 & 19 & 63 & 23 & 87 \\
\hline Partial hand amputation & 49 & 17 & 74 & 14 & 80 \\
\hline $\begin{array}{l}\text { Brachial plexus proceeding to } \\
\text { amputation }\end{array}$ & 37 & 6 & 81 & 5 & 82 \\
\hline Brachial plexus & 65 & 5 & 87 & 7 & 80 \\
\hline Carpal Tunnell & 40 & 3 & 33 & 8 & 43 \\
\hline Arthritis & 50 & Nil & NA & 5 & 41 \\
\hline Hand injury & 53 & 2 & 50 & 3 & 41 \\
\hline Wrist & 49 & 7 & 93 & 7 & 80 \\
\hline CRPS & 68 & 20 & 91 & 29 & 90 \\
\hline Arm pain & 50 & 7 & 66 & 12 & 64 \\
\hline Radiating from neck & 58 & 8 & 79 & 12 & 79 \\
\hline Fracture & 43 & 2 & 81 & 4 & 76 \\
\hline Shoulder & 51 & 12 & 98 & 28 & 77 \\
\hline Tendonitis & 51 & 5 & 45 & 15 & 60 \\
\hline Total & $\mathbf{5 1}$ & $\mathbf{1 1 8}$ & $\mathbf{7 7}$ & $\mathbf{1 7 6}$ & $\mathbf{7 3}$ \\
\hline Anova & $\mathbf{F =}$ & & $\mathbf{F =}$ & & $\mathbf{F =}$ \\
\hline & $\mathbf{4 . 8 0 9}$ & & $\mathbf{2 . 7 5 3}$ & & $\mathbf{2 . 9 9 0}$ \\
$\mathbf{P =}$ & & $\mathbf{P =}=\mathbf{0 0 1}$ & & $\mathbf{0 0 0}$ \\
\hline & $\mathbf{0 0 0}$ & & & & \\
\hline & & & & & \\
\hline
\end{tabular}




\section{Conclusions}

Health professionals have widely recognised that the level of amputation has no relationship to the psychological effects of the injury. The results of using the DASH in this study supports this view.

Many health professionals in Australia also believe that patients with compensable injuries have a higher perceived level of disability than those with non-compensable injuries. This research also supports this belief. It may be that those with compensation develop more anger because they can "blame" another person or organisation for the injury or that the financial reward from litigation also encourages an increased perceived level of disability. The social security system in Australia provides a relatively poor standard of living and it is therefore likely that patients with non-compensable injuries have a financial need to improve their functional status and return to independence and productive employment. Recognition and acceptance of these issues may assist health professionals in simply understanding that compensable patients do have a higher degree of perceived disability and to provide psychological services to assist them adjust to their disability and return to functional independence.

The marked difference in level of disability between brachial plexus injuries which proceed to amputation and those which do not proceed to amputation was surprising. Perhaps it is those patients who accept the long term dysfunction who accept amputation. Acceptance of the injury can aid in reducing the level of disability. It may be that those patients with the brachial plexus amputations are in a more acute phase of their disability whereas the patients who have proceeded to amputation would nearly always be at least 12 months post injury and maybe this time span and treatment during this period results in the differing level of disability. Although all of the brachial plexus injuries who proceeded to amputation, were provided with the chance to use a body-powered prosthesis, most were not successful and most eventually rejected the prosthesis. The difference cannot be attributed to one group of patients having to operate in a one handed fashion while the other have more bilaterality.

Forty-eight patients in 13 diagnostic groups completed the posttreatment DASH. Twelve diagnostic groups, showed a better health status after treatment. The only group that showed a reduced health status were those with pain radiating from the neck. The time between initial completion of the DASH and the post treatment completion varied enormously. The relatively low response level after treatment make it difficult to draw good conclusions from those scores. It may be that those patients who are not responding to treatment ceased attending and did not complete the post treatment DASH. Other patients lived too far away and were referred elsewhere for treatment.

In general there was a relationship between the DASH score and the DASH work and leisure scores with those with the greatest level of perceived disability on the DASH score having the highest perceived level of disability on the work and leisure scores. The work scores are clearly affected by the type of work that the patient normally performs and those whose work involves a lot of manual handling may well perceive themselves as more disabled than those in clerical or professional roles. It may also be that high 
technology equipment provided to upper limb amputees assists them more in the performance of their daily tasks than in the performance of manual handling work tasks and leisure tasks. The compensation system in Australia includes a focus on encouraging employers to offer suitable duties and this may affect a patient's ability to work.

Further research is required to better understand the factors that affect a patient's perception of their disability and assist them to adjust to that disability.

The DASH is a useful scale for measuring the health status of a patient with upper limb dysfunction. It is purported to quantify disability (predominantly physical function). It is a subjective measure designed to measure the patient's perception of their disease. The scale is easy, simple to administer and relevant to a patient's needs. It appears to encompass all cultures. It provides an excellent guide to O.T. treatment. It gives an indication of the needs that the patient sees that they have. We have found it useful for outpatients but for inpatients with a new injury they have not had the chance to attempt the vast majority of the activities and they find it very difficult to complete. The work and leisure modules are phrased differently to the bulk of the DASH items. The bulk of the items are phrased so that the patient rates their level of difficulty in performing the task. However the work and leisure module items compare their difficulty in performing the tasks in a their normal way. This different phraseology may account for some of the results seen in this research.

The measure is very useful for guiding Occupational Therapy treatment and especially focusing on the physical functioning since their injury. If a patient scores the maximum score on the 3 psycho-social items, I use that as indication to discuss referring them to a Psychiatrist. Likewise, severe symptomatology might necessitate a referral to an appropriate pain medicine specialist.

The reason for the differences in the patient's perceived level of disability needs more research especially since their perceived level of disability can have such a marked effect on their performance in tasks.

\section{References:}

1. Donovan-Hall M.K., Yardley L. and Watts RJ: Engagement in activities revealing the body and psychosocial adjustment in adults with a transtibial prosthesis. Prosthetics and Orthotics International, 2002, 26, 1522.

2. Hudak, P.L., Amadio, P.C. Bombardier C \& the Upper Extremity Collaborativ Group: Development of an Upper Extremity outcome Measure: The DASH (Disabilities of the Arm, Shoulder and Hand). American Journal of Industrial Medicine 29: 602-108 (1996)

3. Hunsaker FG, Cioffi DA, Amadio PC Wright JG \& Caughlin B.: The American Academy of Orthopaedic Surgeons Outcomes Instruments.. Journal of Bone and Joint Surgery Vol 84A No. 2 February 2002. 
4. Beaton DE, Katz JN, Fossel, Wright JG \& Tarasuk, V: Measuring the Whole or the Parts? Validity, Reliability and responsiveness of the Disabilities of the Arm, Shoulder and Hand Outcome Measure in Different Regions of the Upper Extremity. Journal of Hand Therapy 2001, Vol 2, Issue 14 p 128-146

5. Davidson J.: A comparison of upper limb amputees and patients with upper limb injuries using the Disability of the Arm, Shoulder and Hand (DASH) Disability and Rehabilitation, 2004: Vol 26, 14/15, 917-923 